\title{
PENGARUH WAKTU FERMENTASI TERHADAP RENDEMEN DAN SIFAT FISIKOKIMIA VCO (Virgin Coconut Oin)
}

\section{[Effect of Fermentation Time on Yield and Physicochemical Properties of VCO (Virgin Coconut Oil)]}

Agustina Cahyani, Agustina Intan Niken Tari ${ }^{*}$, Novian Wely Asmoro

Fakultas pertanian, Jurusan Tekonologi Hasil Pertanian, Universitas Veteran Bangun Nusantara,

Jl. Letjend S. Humardani No 1 Jombor Sukoharjo, Telp (0271)593156, email coresponding author: intanniken@gmail.com

Diterima 20 Februari 2021/ Disetujui 15 Mei 2021

\begin{abstract}
Virgin Coconut Oil (VCO) is coconut oil that is processed by controlled heating or can be produced without heating (fermentation) so that it does not change the composition or aracteristics of the oil. The purpose of this study was to determine the effect of fermentation time on the physical and chemical properties of VCO. This research includes two stages. The first stage is producing VCO based on fermentation time with raw materials such as coconut and tempeh yeast. The second stage performs physical and chemical analysis which includes yield, water content, free fatty acid content and density. This study used a Simple Completely Randomized Design with 1 fermentation time factor (L). There are 4 fermentation times used, namely $L 1=24$ hours, $L 2=36$ hours, $L 3=48$ hours, $\angle 4=60$ hours with 4 replications to obtain 16 experimental units. Further test using DMRT. The results showed that all yields were above $16 \%$. Fermentation time significantly affected the yield, water content, free fatty acid content but had no effect on density. The best results were shown in VCO with 48 hours of fermentation time, namely yield of $21,843 \%$, water content of $0,238 \%$, free fatty acid content of $0,149 \%$ and density of $0,892 \mathrm{~g} / \mathrm{ml}$.
\end{abstract}

Keywords: fermentation, fermentation time, tempeh satrter, Virgin Coconut Oil

\section{ABSTRAK}

Virgin Coconut Oil (VCO) adalah minyak kelapa yang diproses dengan pemanasan yang terkontrol atau dapat dihasilkan tanpa pemanasan (fermentasi) sehingga tidak mengubah komposisi atau karakteristik minyak. Tujuan penelitian ini adalah mengetahui pengaruh waktu fermentasi terhadap sifat fisik dan kimia pada pembuatan VCO. Penelitian ini meliputi dua tahapan. Tahap pertama memproduksi VCO berdasarkan waktu fermentasi dengan bahan baku berupa kelapa dan ragi tempe. Tahap kedua melakukan analisis fisik dan kimiawi yang meliputi rendemen, kadar air, kadar asam lemak bebas dan densitas. Penelitian ini menggunakan Rancangan penelitian Acak Lengkap sederhana dengan 1 faktor waktu fermentasi (L). Waktu fermentasi yang digunakan ada 4 yaitu $\mathrm{L} 1=24 \mathrm{jam}, \mathrm{L} 2=36 \mathrm{jam}, \mathrm{L} 3=48 \mathrm{jam}, \mathrm{L} 4=60$ jam dengan 4 ulangan sehingga diperoleh 16 unit percobaan. Uji lanjut menggunakan DMRT. Hasil penelitian menunjukkan semua rendemen diatas $16 \%$. Waktu fermentasi berpengaruh nyata terhadap rendemen, kadar air, kadar asam lemak bebas namun tidak berpengaruh terhadap densitas. Hasil terbaik ditunjukkan pada VCO dengan perlakuan waktu fermentasi 48 jam, yaitu rendemen 21,843\%, kadar air 0,238\%, kadar asam lemak bebas 0,149\% dan densitas $0,892 \mathrm{~g} / \mathrm{ml}$.

Kata kunci: fermentasi, waktu fermentasi, ragi tempe, Virgin Coconut Oil

\section{PENDAHULUAN}

Tanaman kelapa (Cocos nucifera) merupakan salah satu tanaman tropis yang mudah ditemui di Indonesia dan bermanfaat bagi kehidupan manusia. Hampir seluruh bagian dari pohon kelapa dapat digunakan untuk memenuhi kebutuhan. Bagian utama yang dimanfaatkan adalah daging buah kelapa tua. Daging buah kelapa tua merupakan satu bagian dari kelapa yang bisa diambil santannya untuk dijadikan minyak kelapa murni atau Virgin Coconut Oil (VCO) (Ngatemin dkk., 2013).

Minyak kelapa murni atau Virgin Coconut Oil (VCO) merupakan produk olahan asli Indonesia yang terbuat dari daging kelapa segar 
yang diolah pada suhu rendah atau tanpa pemanasan, sehingga kandungan penting dalam minyak tetap dapat dipertahankan (Tanasale, 2013). Kandungan asam lemak rantai pendek dan sedang pada VCO memberikan manfaat bagi kesehatan manusia diantaranya memberikan stamina pada tubuh, menurunkan berat badan, bersifat sebagai antimikrobia, memelihara kesehatan jantung dan pembuluh darah, serta mencegah timbulnya penyakit degeneratif seperti diabetes, liver, keropos tulang, dan, kanker (Aditiya, Rusmarilin, dan Limbong, 2014).

Minyak kelapa murni (VCO) juga berperan sebagai sumber energi cepat dan merangsang metabolisme, sehingga mampu meningkatkan energi dan menyebabkan penyembuhan penyakit lebih cepat. Hal ini dikarenakan semakin tinggi metabolisme tubuh maka efisiensi sistem kekebalannya semakin bagus (Marlina dkk, 2017)

Proses pembuatan VCO di Indonesia ada beberapa metode yaitu: metode pemanasan terkontrol (dengan cara memanaskan krim santan $<95{ }^{\circ} \mathrm{C}$ hingga menghasilkan minyak), metode pemanasan bertahap (dilakukan dengan memanaskan santan pada suhu $<90{ }^{\circ} \mathrm{C}$ kemudian minyak yang diperoleh dipanaskan kembali dengan suhu rendah $\left(<65^{\circ} \mathrm{C}\right)$ ), metode pancingan minyak (dilakukan dengan menambahkan minyak pancing ke dalam santan dengan perbandingan tertentu), metode pengadukan (dilakukan pengadukan terusmenerus, sehingga molekul protein yang berfungsi sebagai emulsifier rusak sehingga ikatan lemak-protein terputus dan minyak dapat terpisah), metode sentrifugasi (dilakukan dengan memutuskan ikatan lemak-protein pada santan dengan cara pemutaran (pemusingan), yaitu dengan gaya sentrifugal) (Pontoh dkk., 2008).

Selain metode tersebut, pembuatan VCO dapat dilakukan dengan metode fermentasi. Metode fermentasi pembuatan VCO adalah metode yang dilakukan dengan penambahan ragi sebagai starter untuk proses pemecahan emulsi krim/ santan sehingga mendapatkan VCO yang diinginkan (Apriyantono dan Maharun, 2014) Salah satu ragi sebagai starter pada pembuatan VCO adalah ragi tempe, yang didalamnya mengandung Rhyzopus oligosporus, Rhyzopus oryzae, Rhyzopus stolonifer, Rhyzopus chlamdosporus, dan Rhyzopus arrhizus. Rhyzopus oligosporus lebih banyak mensintesis enzim pemecah protein (protease) dan Rhyzopus oryzae lebih banyak mensintesis enzim pemecah pati (alfa amilase) selama proses fermentasi. Pada umumnya ragi tempe, mengandung kadar Rhyzopus oligosporus lebih banyak daripada kadar Rhyzopus dari genus lainnya, dengan perbandingan 2:1. Enzim protease akan memecah lapisan protein yang melapisi emulsi di dalam santan sehingga protein di dalam santan kehilangan sifat aktif permukaannya dan setelah partikel terpecah akan terbentuk minyak. Selama proses fermentasi, Rhyzopus oryzae lebih banyak mensintesis enzim pemecah pati dibanding dengan enzim pemecah protein (enzim protease). Menurut Mujdalifah (2016), enzim protease yang tinggi akan dengan cepat dan lebih banyak memecah partikel dalam krim santan, sehingga akan berpengaruh pada rendemen, kadar air dan kadar minyak..

Pembuatan VCO dengan metode fermentasi sangat bergantung pada waktu fermentasi. Apabila fermentasi dilakukan terlalu lama, maka akan menghasilkan minyak dengan rendemen tinggi namun kualitas minyak yang diperoleh dibawah standar SNI 7381:2008 dan APCC, sebaliknya jika dilakukan terlalu singkat maka pemecahan belum sempurna.

Proses ekstraksi secara fermentasi dibandingkan cara lain adalah kemudahannya, sehingga dapat diproduksi secara praktis, hemat bahan bakar, residu blondo lebih sedikit, tingkat ketengikan rendah dengan daya simpan lebih lama, aroma harum, dan bebas senyawa penginduksi kolesterol (Ngatemin, dkk., 2013)

Beberapa penelitian pembuatan VCO dengan metode fermentasi telah dilakukan, antara lain pembuatan VCO menggunakan beberapa jenis konsentrasi starter Rhyzopus oligosporus (Aswani dan Mira, 2016), pembuatan VCO menggunakan beberapa jenis ragi tradisional (Mudjdalipah, 2016), dan pembuatan VCO menggunakan starter Saccharomyces cereviceae selama waktu 14,16,18,20, 22 dan 24 jam (Ngatemin, dkk., 2013)

Penelitian oleh Handayani (2016), bertujuan untuk memperoleh hasil VCO yang optimal, dilakukan pemurnian menggunakan 
metode adsorpsi melalui media berpori. Media berpori yang mudah ditemui adalah zeolit alam. Hasil yang optimal dapat diperoleh $\pm 13,33 \%$ VCO dari jumlah VCO yang akan disaring. Pemurnian menggunakan batu mampu menyerap partikel-partikel dan kotoran yang terdapat pada minyak sehingga dihasilkan rendemen, asam lemak bebas dan kadar air yang optimal

Berdasarkan uraian tersebut, penelitian ini bertujuan untuk mengetahui pengaruh waktu fermentasi terhadap hasil rendemen VCO, karakteristik fisik (densitas) dan kimianya (kadar air dan kadar asam lemak bebas) yang mendekati SNI 7381:2008 Virgin Coconut Oil (VCO)

\section{BAHAN DAN METODE}

Bahan

Bahan baku yang digunakan dalam pembuatan VCO adalah kelapa tua parut 3 butir, air, ragi tempe merk raprima, kertas saring dan batu zeolit. Bahan yang digunakan dalam analisis asam lemak bebas adalah etanol $95 \%$, indikator $\mathrm{PP}, \mathrm{NaOH} 0,1 \mathrm{~N}$.

Metode

Pembuatan VCO diawali dengan pemarutan kelapa kemudian dilanjutkan dengan penambahan air perbandingan 1:2. Peremasan dan penyaringan dilakukan untuk menghasilkan santan. Santan kemudian didiamkan selama 2 jam, sehingga terbentuk dua lapisan yaitu lapisan atas berupa krim santan dan lapisan bawah berupa air. Air kemudian dilakukan pembuangan. Krim santan yang terbentuk dimasukkan ke dalam beker gelas, kemudian dilakukan penambahan ragi sebanyak $2 \mathrm{gr}$ dan dilakukan pengadukan. Setelah tercampur rata dilakukan pemasukkan dalam toples kemudian tutup tetapi tidak terlalu rapat (sedikit terbuka). Fermentasi dilakukan selama 24 jam, 36 jam, 48 jam dan 60 jam. Hasil fermentasi akan menghasil-kan air, blondo (protein) dan minyak. Penelitian ini dilakukan menggunakan perlakuan waktu fermentasi. Waktu fermentasi yang digunakan ada 4 varian yaitu $L_{1}=24$ jam, $L_{2}=$ $36 \mathrm{jam}, \mathrm{L}_{3}=48 \mathrm{jam}, \mathrm{L}_{4}=60 \mathrm{jam}$. Masing- masing perlakuan dilakukan dengan 4 ulangan sehingga diperoleh 16 unit percobaan.

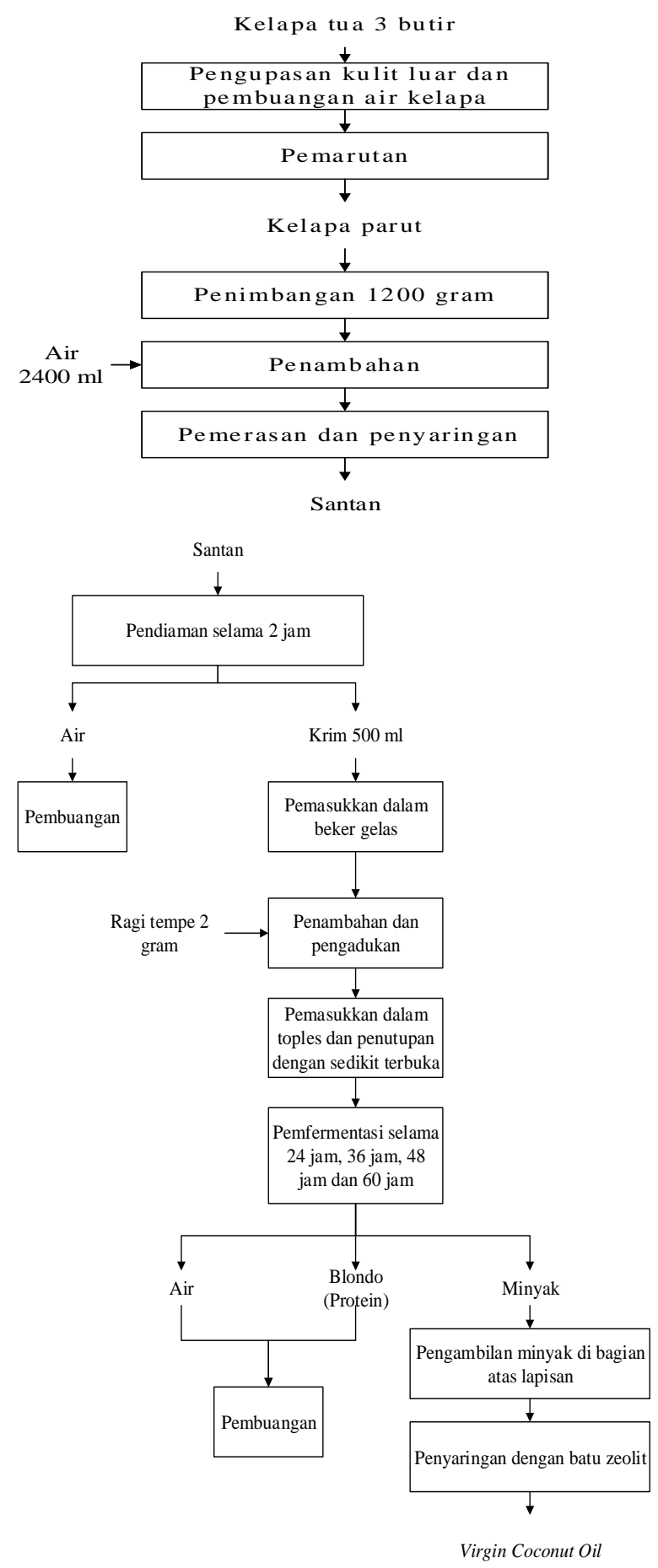

Gambar 1 Diagram Alir Pembuatan Santan dan VCO

Data yang diperoleh dianalisis sidik ragamnya menggunakan One way ANOVA Apabila terdapat perbedaan antar perlakuan dilanjutkan uji beda 
nyata menggunakan Duncan Multiple Range Test (DMRT) pada tingkat signifikansi 0,05. Pengolahan data hasil penelitian menggunakan program SPSS 17. Setelah dihasilkan VCO dilakukan analisis seperti Tabel 1 dan hasil analisis yang diperoleh kemudian dibandingkan dengan Standard Nasional Indonesia dan APCC.

Tabel 1 Metode Analisis Virgin Coconut Oil Jenis Analisis Metode

\begin{tabular}{|c|c|c|}
\hline 1. & Rendemen & Sudarmadji dkk, 1997 \\
\hline 2. & Kadar air & $\begin{array}{l}\text { Thermogravimetri } \\
\text { (SNI 7381:2008) }\end{array}$ \\
\hline 3. & $\begin{array}{l}\text { Kadar asam } \\
\text { lemak bebas } \\
\text { (FFA) }\end{array}$ & $\begin{array}{l}\text { Dihitung sebagai asam } \\
\text { laurat } \\
\text { (SNI 7381:2008) }\end{array}$ \\
\hline 4. & Densitas & Sudarmadji dkk, 1997 \\
\hline
\end{tabular}

\section{HASIL DAN PEMBAHASAN}

Pada Gambar 2 terlihat bahwa semakin lama waktu fermentasi maka rendemen yang dihasilkan meningkat

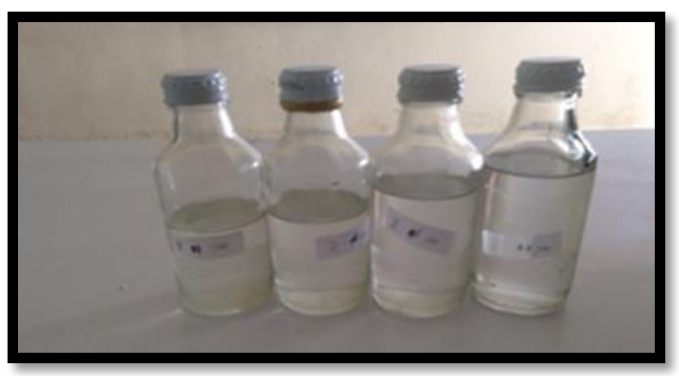

Gambar 2. Rendemen VCO yang dihasilkan dari perbedaan waktu fermentasi $(24,36$, 48 dan 60 jam).

\section{a. Rendemen}

Rendemen VCO dihitung berdasarkan bobot VCO yang diperoleh dibandingkan dengan bobot bahan yang digunakan (parutan daging buah kelapa). Rendemen hasil (\%) = (a: b) x $100 \%$. keterangan $\mathrm{a}=$ bobot bahan (VCO) yang diperoleh $(\mathrm{g}) \mathrm{b}=$ bobot bahan yang digunakan (parutan daging buah). Menurut Aswani (2012), hasil rendemen minyak VCO minimal $16 \%$. Hasil penelitian menunjukkan semakin lama fermentasi hasil rendemen semakin tinggi dan lebih dari $16 \%$.
Pada Gambar 3 terlihat rendemen VCO dengan perlakuan waktu fermentasi menunjukan beda nyata $(p<0,05)$ antar perlakuan. Rendemen VCO pada perlakuan waktu fermentasi 24, 36, 48 dan 60 jam berturut-turut sebesar 17,538\%, 19,343, $21,843 \%$ dan $23,071 \%$. Gambar 3 tersebut menunjukkan bahwa semakin lama waktu fermentasi maka rendemen VCO yang dihasilkan semakin tinggi.

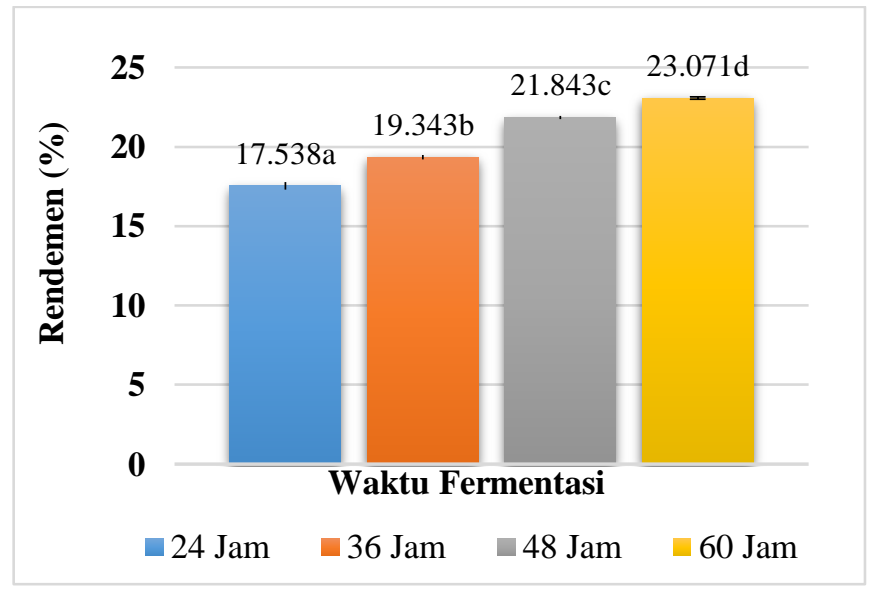

Gambar 3 Rendemen VCO pada berbagai waktu fermentasi

Keterangan: huruf yang sama dibelakang angka menunjukkan tidak ada bedanyata

Menurut Witono dkk (2007), semakin lama waktu fermentasi maka rendemen yang dihasilkan akan semakin tinggi. Hal ini disebabkan karena semakin lama waktu fermentasi maka semakin banyak jumlah substrat protein pada santan yang berinteraksi dengan enzim protease. Enzim protease akan memecah lapisan protein yang melapisi emulsi di dalam santan sehingga protein di dalam santan kehilangan sifat aktif permukaannya dan setelah partikel terpecah akan terbentuk minyak. akibatnya semakin banyak minyak terpisah dari protein dan minyak yang dihasilkan semakin banyak, dan rendemen yang dihasilkan semakin tinggi.

\section{b. Kadar Air}

Kadar air hasil analisis dibandingkan dengan SNI VCO. Menurut SNI VCO (7381:2008) menyatakan bahwa besarnya kadar air VCO maksimal adalah 0,2\%. Pada Gambar 4 menunjukkan kadar air VCO dengan perlakuan 
waktu fermentasi. Kadar air VCO 24 jam fermentasi adalah $0,285 \%$, Kadar air VOC pada 36 jam fermentasi, 48 Jam fermentasi dan 60 jam fermentasi berturut-turut adalah 0,238 \%, $0,173 \%$ dan $0,285 \%$. Kadar air tertinggi terdapat pada VCO dengan perlakuan waktu fermentasi 60 jam. Hasil penelitian ini menunjukkan bahwa kadar air VCO dengan waktu fermentasi 24 jam, 36 jam dan 60 jam lebih dari 0,2\%, sedangkan kadar air VCO dengan waktu fermentasi 48 jam dibawah 0,2\%. Apabila merujuk SNI, Kadar air VCO dengan waktu fermentasi 48 jam adalah yang paling sesuai. Apabila merujuk standar mutu VCO yang dikeluarkan Asian Pacific Coconut Community (APCC) yang menyatakan kadar air VCO berkisar antara 0,1\%-0,5\%, maka semua perlakuan waktu fermentasi VCO menunjukkan kadar air yang sudah sesuai dengan standar APCC tersebut.

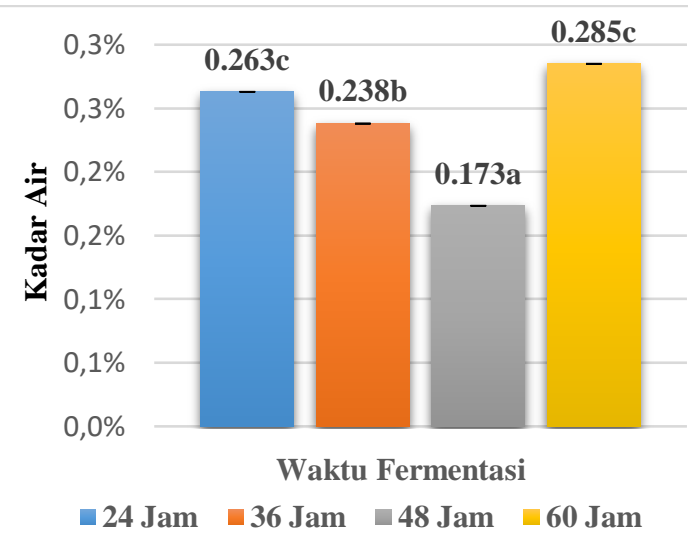

Gambar 4. Kadar Air VCO dengan berbagai waktu fermentasi

Keterangan: huruf yang sama dibelakang angka menunjukkan tidak ada bedanyata

Pada Gambar 4, terlihat bahwa kadar air VCO dengan waktu fermentasi 60 jam paling tinggi, yaitu $0,28 \%$. Hal ini dapat terjadi, karena krim santan difermentasi menggunakan ragi tempe. Di dalam ragi tempe terdapat jamur Rhizopus oligosporus dan Rhizopus oryzae. Salah satu jamur tempe yaitu Rhizopus oligosporus mampu menghasilkan metabolit berupa enzim protease. Selama proses fermentasi inilah enzim protease akan memecah lapisan protein yang melapisi emulsi di dalam santan sehingga protein di dalam santan kehilangan sifat aktif permukaannya dan setelah partikel terpecah akan terbentuk minyak. Semakin lama fermentasi maka aktifitas pemecahan juga banyak sehingga dihasilkan minyak dalam jumlah banyak, namun apabila fermentasi terlalu lama dapat menyebabkan aktifitas pemecahan enzim berhenti, dan menyebabkan partikel lain masuk kedalam minyak. Hal ini menyebabkan kandungan minyak tidak murni lagi dan menyebabkann kadar air minyak menjadi tinggi. Kadar air yang tinggi akan berpengaruh terhadap sifat hidrolisis minyak, yaitu minyak lebih cepat terhidrolisis menghasilkan asam lemak bebas dan gliserol dengan senyawa antara air.

Menurut Aditiya dkk (2014), semakin lama waktu fermentasi maka kadar air yang dihasilkan akan semakin tinggi. Hal ini dikarenakan semakin lama fermentasi maka semakin tinggi proses pelepasan air dari krim santan dan semakin lama pula berinteraksi dengan udara (oksigen).

Kadar air VCO perlakuan waktu fermentasi 24 jam sebesar 0,268\%. Tingginya kadar air ini diduga waktu 24 jam fermentasi tersebut enzim protease belum sempurna memecah ikatan antara protein, minyak, sehingga masih ada air yang lolos dalam minyak.

\section{c. Kadar Asam Lemak Bebas}

Asam lemak bebas adalah asam lemak yang dilepas ketika terjadi reaksi hidrolisis, dihitung sebagai asam laurat dengan syarat SNI (7381:2008) yaitu maksimal $0,2 \%$.

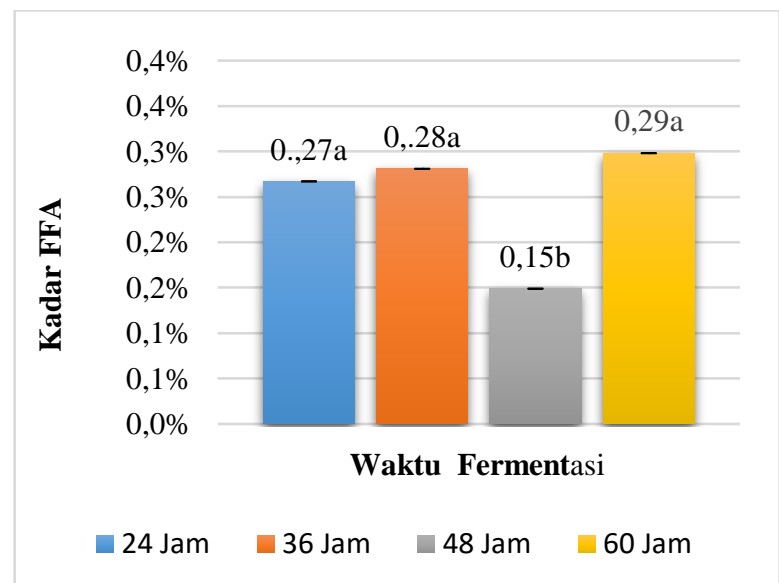

Gambar 5. Kadar Asam Lemak Bebas VCO dengan berbagai waktu fermentasi.

Keterangan: huruf yang sama dibelakang angka menunjukkan tidak ada bedanyata 
Pada Gambar 5 menunjukkan bahwa kadar asam lemak bebas VCO tertinggi terjadi pada perlakuan waktu fermentasi 24 dan 60 jam, masing-masing sebesar 0,27 \% dan 0,298\%, namun kedua perlakuan tersebut tidak memenuhi syarat SNI (7381:2008) yaitu 0,2\%. Kadar asam lemak bebas VCO terendah diperoleh pada perlakuan waktu fermentasi 48 jam sebesar $0,149 \%$. Hasil ini memenuhi syarat SNI (7381:2008), karena di bawah 0,2\%. Apabila dibandingkan dengan syarat APCC yaitu kadar asam lemak $<0,5 \%$, maka semua perlakuan waktu fermentasi tersebut memenuhi syarat APCC.

Tingginya kadar asam lemak bebas pada VCO ini berbanding lurus dengan besarnya kadar air. Hal ini disebabkan asam lemak bebas merupakan hasil reaksi hidrolisis, yang disebabkan oleh sejumlah air. Adanya air dalam minyak menyebabkan minyak akan mudah terhidrolisis membentuk gliserol dan asam lemak bebas (Anwar dan Salima, 2016). Menurut Waisundara et.al, (2004) hasil VCO dengan \%FFA yang tinggi disebabkan karena globula minyak pada santan masih belum terpisah sempurna dengan air sehingga air masih tercampur dalam minyak. Semakin lama fermentasi maka interaksi antara minyak dengan air (baik dari santan maupun dari udara atau oksigen) maka semakin mudah terjadi hidrolisis VCO, akibatnya kadar FFAyang dihasilkan semakin tinggi.

\section{d. Densitas}

Pada Gambar 6 terlihat bahwa densitas VCO dengan perlakuan waktu fermentasi 24,36 , 48 dan 60 jam menghasilkan densitas masingmasing $0,893 \mathrm{~g} / \mathrm{ml}, 0,892 \mathrm{~g} / \mathrm{ml}, 0,892 \mathrm{~g} / \mathrm{ml}$ dan $0,887 \mathrm{~g} / \mathrm{ml}$. Hasil tersebut tidak berbeda nyata, ditunjukkan dengan huruf dibelakang angka yang sama.

Jika dilihat dari hasil standar APCC maka densitas VCO yang diperoleh tidak memenuhi standar. Densitas merupakan salah satu parameter yang digunakan untuk menentukan kualitas suatu minyak, semakin tinggi nilai densitas maka semakin rendah kualitas minyak tersebut.
Densitas dipengaruhi oleh air, berat molekul dan komponen-komponen dalam minyak, sehingga semakin besar berat molekul maka densitasnya juga akan semakin besar (Simangungsongdkk., 2016) Menurut Gustiana (2008), ketidak jenuhan komponen asam lemak yang tinggi juga dapat menaikkan densitas. Kadar air dan komponen-komponen lain seperti kotoran, protein, dan garam mineral dalam minyak yang dapat lolos masuk ke dalam minyak pada proses penyaringan juga berpengaruh.

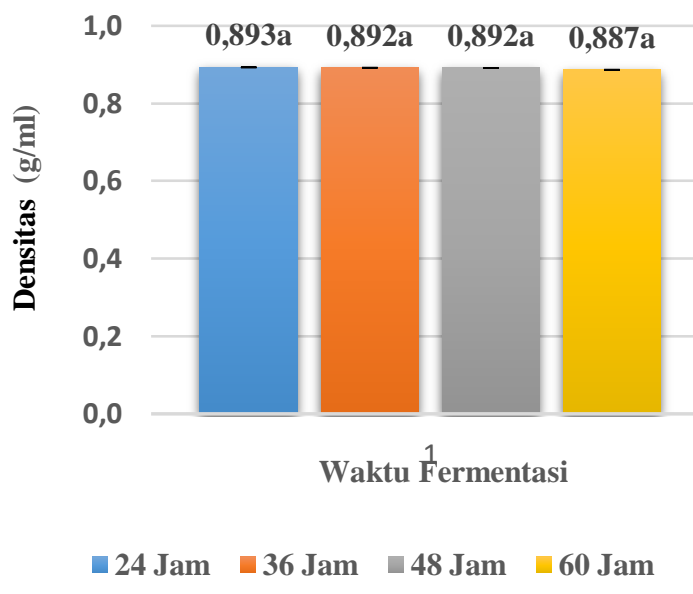

Gambar 6. Densitas VCO dengan berbagai waktu fermentasi

Keterangan: huruf yang sama dibelakang angka menunjukkan tidak ada bedanyata

\section{KESIMPULAN}

Kesimpulan penelitian ini adalah bahwa waktu fermentasi berpengaruh nyata terhadap rendemen, kadar air, dan kadar asam lemak bebas (FFA) tetapi tidak berpengaruh terhadap densitas VCO. Rendemen VCO tertinggi diperoleh pada waktu fermentasi 60 jam sebesar 23,072\%. Hasil kadar air VCO terbaik pada perlakuan waktu fermentasi 48 jam sebesar 0,173\%. Kadar asam lemak bebas VCO terbaik pada perlakuan waktu fermentasi 48 jam sebesar 0149\%. Rendemen VCO tertinggi diperoleh pada perlakuan waktu fermentasi 60 jam sebesar 23,071\%.

Hasil VCO terbaik pada perlakuan 48 jam dengan kadar air 0,173\%, kadar asam lemak bebas 0,149\% dan densitas 0, $892 \mathrm{~g} / \mathrm{ml}$, dan sudah memenuhi syarat SNI 
Versi Online:

http://www.profood.unram.ac.id/index.php/profood e-ISSN: 2443-3446

\section{DAFTAR PUSTAKA}

[APCC] Asian Pasific Coconut Community. 2005. Standard for virgin coconut oil. http://www.apccsec.org/article-coconut. html. [January 2019].

Aditiya, R., Rusmarilin, H., \& Limbong, L. N. 2014. Optimasi Pembuatan Virgin Coconut Oil (VCO) dengan Penambahan Ragi Roti (Saccharomyces cerevisiae) dan Lama Fermentasi dengan VCO Pancingan. Jurnal Rekayasa Pangan dan Pertanian. Vol 2(2) 51-57.

Aditiya, Riko. 2014. Optimasi Pembuatan Virgin Coconut Oil (VCO) dengan Pnambahan Ragi Roti (Saccharomyces cerevisiae) dan Lama Fermentasi dengan VCO Pancingan. Jurnal Rekayasa Pangan dan Pertanian. Vol 2(3): 27-51.

Anwar, C., \& Salima, R. (2016). Perubahan Rendemen Dan Mutu Virgin Coconut Oil (VCO) pada Berbagai Kecepatan Putar dan Lama Waktu Sentrifugasi. Teknotan: Jurnal Industri Teknologi Pertanian. Vol 10(2) 51-60.

Aswani, Mira. 2016. Pembuatan Virgin Coconut Oil (VCO) dengan Metode Fermentasu Menggunakan Rhizopus Oligosporus. Jurnal Teknologi Pangan. Universitas Syiah Kuala. Vol 1 (1).

Gustiani, S. H., 2008. Studi Ekstraksi Analisis Minyak Lengkeng [Skripsi]. FMIPA UI, Jakarta.

Marlina, Dwi Wijayanti, Ivo Pangesti Yudiastari, dan Lilis Safitri. 2017. Pembuatan Virgin Coconut Oil dari Kelapa Hibrida Menggunakan Metode Penggaraman dengan Nacl dan Garam Dapur. Jurnal Chemurgy. Vol 1(2) 7-11.

Mujdalipah, Siti. 2016. Pengaruh Ragi Tradisional Indonesia dalam Proses Fermentasi Santan terhadap Karakteristik Rendemen, Kadar Air, dan Kadar Asam Lemak Bebas Virgin Coconut Oil (VCO). Jurnal Pendidikan UPI. Vol 1(1).

Ngatemin., Nurrahman dan Joko Teguh Isworo. 2013. Pengaruh Lama Fermentasi pada Produksi Minyak Kelapa Murni (Virgin Coconut Oi) terhadap Sifat Fisik, Kimia dan Organoleptik. Jurnal Pangan dan Gizi. Vol 4(8) : 1-5.
Pro Food (Jurnal Ilmu dan Teknologi Pangan)

Vol 7 No. 1 Mei 2021

ISSN: 2443-1095

Pontoh, J., Surbakti M. B dan Papilaya M. 2008. Kualitas Virgin Coconut Oil dari Beberapa Metode Pembuatan. Journal Chemistry Progress. Vol 1(1) 60-65.

Sri Handayani, Enjarlis. 2016. Pemurnian Virgin Coconut Oil Menggunakan Zeolit 3A sebagai Bahan Baku Obat Kulit. Jurnal Bahan Alam Terbarukan. Vol 5(2) 61-67.

Standar Nasional Indonesia. 2008. Syarat Mutu Virgin Coconut Oil. SNI 7381:2008.

Waisundara, V. Y., Perera C. O dan Barkiw. 2004. Effect of Different Pre-Treatment of Fresh Coconut Kernels on Some of the Quality Attributes of the Coconut Milk Extracted. Department of Chemistry, Food Science and Technology Program of National University of Singapore. 771777.

Witono Y, Aulanni'am, Subagio A, dan Widjanarko SB. 2007. Ekstraksi Virgin Coconut Oil Secara Enzimatis Menggunakan Protease dari Tanaman Biduri (Calotropis gigantea). Jurnal Agritech. Vol 27: 100-106. 